\title{
EFEKTIVITAS PENGGUNAAN VIRGIN COCONUT OIL (VCO) DAN MINYAK ZAITUN UNTUK PENCEGAHAN LUKA TEKAN GRADE I PADA PASIEN YANG BERISIKO MENGALAMI LUKA TEKAN DI RSU KABUPATEN TANGERANG.
}

\author{
Siti Wasliyah ${ }^{1}$ \\ ${ }^{1}$ Poltekkes Kemenkes Banten
}

\begin{abstract}
ABSTRAK
Luka tekan telah digambarkan sebagai salah satu kompliasi yang paling mahal dan melemahkan fisik pada abad ke-20. Luka tekan adalah gangguan ketiga yang paling mahal setelah kanker dan penyakit kardiovaskuler.( Agrawal Karron, Chuhan Neha,2012). Bahan-bahan alami banyak dianjurkan pada perawatan kulit di Indonesia antara lain adalah minyak kelapa dan minyak zaitun. Penelitian Handayani, 2010 dan Yolanda, 2010 mendapatkan hasil bahwa virgin coconut oil (VCO) dan minyak zaitun efektif untuk mencegah luka tekan. Penelitian ini adalah penelitian kuasi eksperimen dengan pendekatan pretest and postets group design, bertujuan untuk mengidentifikasi efektifitas penggunaan VCO dan minyak Zaitun dengan massage dalam mencegah luka tekan pada pasien yang berisiko mengalami luka tekan di RSU kabupaten Tangerang. Penelitian dilakukan di ruang rawat inap bedah RSU Kabupaten Tangerang pada bulan Oktober - Desember 2016 dengan populasi pasien yang berisiko mengalami luka tekan grade 1. Metode sampling yang digunakan adalah consecutive sampling berjumlah 14 orang untuk masing-masing perlakuan. Data hasil observasi mengacu pada kriteria karakteristik luka grade I Non Bleacheable Erytema yang telah dibuat oleh EPUAP dan NPUAP (2009). Analisa bivariat Uji T independent mendapatkan hasil tidak ada perbedaan rerata pada kedua kelompok mengenai tingkat kefektifan kedua metode terhadap pencegahan luka tekan grade I , sebelum dan setelah dilakukan massage menggunakan VCO dan minyak zaitun dimana $\mathrm{p}$ value menunjukkan angka $0,230(P$ value $>0,05)$.
\end{abstract}

Kata kunci : Luka Tekan, virgin coconut oil (VCO), Minyak Zaitun

Korespondensi: Siti Wasliyah .E-mail: siti.wasliyah@poltekkesbanten.ac.id

\section{PENDAHULUAN}

Luka Tekan adalah cedera pada kulit sebagai akibat dari tekanan konstan karena gangguan mobilitas. Tekanan diakibatkan karena berkurangnya aliran darah dan akhirnya menyebabkan kematian sel, kerusakan kulit dan pengembangan luka terbuka (Zeller John L,2006). Luka tekan telah digambarkan sebagai salah satu kompliasi yang paling mahal dan melemahkan fisik pada abad ke-20. Luka tekan adalah gangguan ketiga yang paling mahal 
setelah kanker dan penyakit tindakan yang murah, tidak kardiovaskuler.(Agrawal Karron, menimbulkan bahaya dan Chuhan Neha,2012). Epidemiologi memungkinkan untuk luka tekan bervariasi di beberapa diimplementasikan namun tempat, insiden berkisar antara $0,4 \%$ - keuntungan dan efektifitas bahan $38 \%$ di unit perawatan akut, 2,2\%- topikal spesifik mana yang lebih $23,9 \%$ di unit perawatan jangka simpel belum dijelaskan panjang, $0 \%-7 \%$ di home care (reddy,2006). Bahan-bahan alami (perawatan di rumah) (Lyder banyak dianjurkan pada perawatan CH,2003 dan Reddy et al, 2006). kulit di Indonesia antara lain adalah Pada fasilitas pelayanan kesehatan minyak kelapa dan minyak zaitun. geriatri di Jepang, 91\% dari total Penelitian Handayani, 2010 populasi pasien yang imobilisasi mengalami luka tekan. Luka tekan pada pasien merupakan masalah yang sedang menjadi perhatian bagi perawatan serta tenaga medis. Banyak hal telah dilakukan untuk memahami proses penyakit, termasuk terbentuknya organisasi di negaranegara Eropa yang khusus membahas mengenai luka tekan. (Agrawal Karron, Chuhan Neha,2012).

Pengkajian kulit yang rutin, reposisi yang teratur, managemen kelembaban kulit dan support nutrisi merupakan intervensi yang umum untuk mencegah terjadinya luka tekan. (Jankowski Irene M, 2010) Perawatan kulit menggunakan pelembab diyakini merupakan mendapatkan hasil yang bermakna pada penggunaan VCO untuk pencegahan luka tekan dengan massage. VCO merupakan minyak kelapa murni yang mengandung $10 \%$ asam lemak tak jenuh sangat bermanfaat bagi kesehatan tubuh, sedangkan asam lemak jenuh yang terdiri dari $8 \%$ asam laurat dan asam oleat serta asam lemak lainnya dapat melembutkan kulit. Selain itu VCO mengandung vitamin E. (Amin, 2009).

Beberapa penelitian (sourthen Illinois University dan Purdue University tahun 2007) menunjukkan bahwa VCO mempunyai manfaat menguragi infamasi, memperbaiki penyembuhan jaringan, membunuh 
bakteri, dan menambah fungsi sistem imun pada pasien AIDS. (Joseph Midhun, 2010). Penelitian Yolanda Oktrari, dkk, 2010 juga mendapatkan hasil yang bermakna pada penggunaan minyak zaitun untuk pencegahan luka tekan dengan massage. Minyak zaitun mengandung asam oleat hingga $80 \%$ dapat mengenyalkan kulit dan melindungi elastisitas kulit dari kerusakan (Surtiningsih, 2005).

Penelitian Handayani dan Yolanda hanya menggunakan satu perlakuan saja sehingga perlu dilakukan penelitian lanjutan untuk melihat efektivitas antara penggunaan VCO dan minyak zaitun (dua perlakuan) untuk pencegahan luka tekan, yang akan dilakukan pada penelitian ini.

\section{METODE}

Desain

penelitian

menggunakan quasi experiment dengan pendekatan Pretest-Posttest Control Group Design. Pada penelitian ini terdapat dua kelompok, yaitu kelompok intervensi dan kelompok kontrol yaitu kelompok intervensi A (VCO) berjumlah 7 responden dan kelompok intervensi B berjumlah 7 responden (minyak zaitun). Kelompok diberi perlakuan berupa perawatan pencegahan standar dengan VCO atau minyak zaitun dengan massage ringan berupa efflurage 4-5 menit (Elliz \& Bentz, 2007) di daerah scapula, sacrum dan tumit. Sampel pada penelitian ini pasien yang beresiko terjadi luka tekan di RSU kabupaten Tangerang. Teknik pengumpulan sampel yang digunakan adalah consecutive sampling, dimana sampel ditetapkan berdasarkan responden yang memenuhi kriteria inklusi. Penelitian ini dilakukan di ruang rawat inap bedah dan penyakit dalam RSU Kabupaten Tangerang pada bulan Oktober sampai dengan Desember 2016. Analisa Univariat untuk mengetahui distribusi karakteristik responden. Analisa bivariat bertujuan untuk mengetahui Pengaruh VCO dan Minyak Zaitun terhadap pencegahan luka tekan grade I. Uji statistik yang digunakan adalah Uji $\mathrm{T}$ dependent dan $\mathrm{T}$ independent. 


\section{HASIL}

\section{Analisis Univariat}

\section{Karakteristik responden penelitian}

Karakteristik responden pada penelitian ini terdiri dari usia, jenis kelamin, diagnosa medis, kategori risiko dan riwayat merokok. Karakteristik responden berdasarkan usia dalam variabel numeric dianalisis menggunakan analisis deskriptif explore disajikan dalam tabel 1

Tabel 1.

Distribusi frekuensi responden berdasarkan usia di Ruang Rawat Inap Bedah RSU Kabupaten Tangerang Tahun 2016 ( $\mathrm{n}=18)$

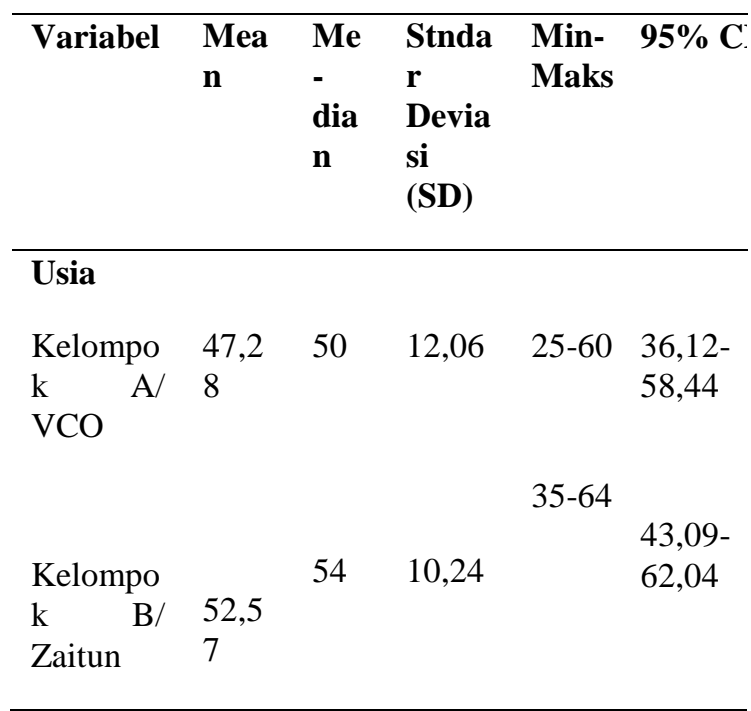

Hasil penelitian didapatkan rata-rata umur responden pada kelompok A adalah 47,28 dengan standar deviasi 12,04 dan kelompok
B adalah 52,57 dengan standar deviasi 10,24.Umur termuda pada kelompok A adalah 25 tahum dan tertua 60 tahun sedangkan pada kelompk B responden termuda adalah 35 tahun dan tertua adalah 64 tahun. Hasil estimasi interval diyakini $95 \%$ rata-rata usia responden kelompok $\mathrm{A}$ 36,12 hingga 58,44, sedangkan kelompok B 43,09 hingga 62,04 tahun.

Karakteristik responden berdasarkan jenis kelamin dalam variable nominal dibagi menjadi dua kategori yaitu perempuan dan lakilaki.

Tabel 2.

Distribusi frekuensi responden berdasarkan jenis kelamin di Ruang rawat Inap Bedah RSU Kabupaten

Tangerang Tahun $2016(n=14)$

\begin{tabular}{llllllll}
\hline Variabel Kategori & \multicolumn{3}{l}{$\begin{array}{l}\text { Kelompok Kelompok Jumlah } \\
\end{array}$} & A/VCO & \multicolumn{2}{c}{ B/Zaitun } & \\
\cline { 3 - 8 } & & N & $\%$ & N & $\%$ & N & $\%$ \\
& & & & & & & \\
\hline $\begin{array}{l}\text { Jenis } \\
\text { Kelamin }\end{array}$ & Perempuan & 5 & 71,4 & 2 & 28,6 & 7 & 100 \\
& Laki-laki & 2 & 28,6 & 5 & 71,4 & 7 & 100 \\
\hline Jumlah & 7 & 100 & 7 & 100 & 14 & 100
\end{tabular}

Tabel 2 menunjukkan distribusi frekuensi responden berdasarkan karakteritik jenis 
Siti Wasliyah. Efektivitas Penggunaan VCO.

kelamin yaitu pada kelompok A/VCO berjenis kelamin perempuan sebanyak 5 orang $(71,4 \%)$ dan pada kelompok B/Zaitun sebanyak 2 orang (28,6\%). Jumlah keseluruhan responden berjenis kelamin perempuan sebanyak 7 orang. Responden yang berjenis kelamin laki-laki pada kelompok A/VCO sebanyak 2 orang $(28,6 \%)$ dan pada kelompok zaitun sebanyak 5 orang (71,4\%). Jumlah keseluruhan responden berjenis kelamin laki-laki adalah 7 orang (100\%).

\section{Diagnosa Medis}

Tabel 3

Distribusi frekuensi responden berdasarkan diagnosa medis di Ruang Rawat Inap Bedah RSU Kabupaten Tangerang Tahun $2016(\mathrm{n}=14)$

\begin{tabular}{|c|c|c|c|c|c|c|c|}
\hline \multirow[t]{2}{*}{ Variabel } & \multirow[t]{2}{*}{ Kategori } & \multicolumn{2}{|c|}{$\begin{array}{l}\text { Kelompok } \\
\text { A/VCO }\end{array}$} & \multicolumn{2}{|c|}{$\begin{array}{l}\text { Kelompok } \\
\text { B/Zaitun }\end{array}$} & \multicolumn{2}{|c|}{ Jumlah } \\
\hline & & $\mathbf{N}$ & $\%$ & $\mathbf{N}$ & $\%$ & $\mathbf{n}$ & $\%$ \\
\hline \multirow{6}{*}{$\begin{array}{l}\text { Diagnosa } \\
\text { Medis }\end{array}$} & Dyspnea/asma & 2 & 28,5 & 2 & 28,5 & 4 & 28,5 \\
\hline & Anemia & 2 & 28,5 & 2 & 28,5 & 4 & 28,5 \\
\hline & Stroke & 2 & 28,5 & 0 & 0 & 2 & 14,2 \\
\hline & Hypoalbumin & 1 & 14,5 & 0 & 0 & 1 & 7,3 \\
\hline & DM & 0 & 0 & 1 & 14,5 & 1 & 7,3 \\
\hline & Fraktur & 0 & 0 & 2 & 28,5 & 2 & 14,2 \\
\hline Jumlah & & 7 & 100 & 7 & 100 & 14 & 100 \\
\hline
\end{tabular}

Tabel menunjukkan sebagian besar responden dalam penelitian ini adalah pasien dengan diagnose medis dyspnea dan anemia.

\section{Kategori Risiko Luka Tekan}

Tabel 4.

Distribusi frekuensi responden berdasarkan kategori risiko luka tekan di Ruang Rawat Inap Bedah RSU Kabupaten Tangerang Tahun 2016 $(n=14)$

\begin{tabular}{|c|c|c|c|c|c|c|c|}
\hline \multirow[t]{2}{*}{ Variabel } & \multirow[t]{2}{*}{ Kategori } & \multicolumn{2}{|c|}{$\begin{array}{l}\text { Kelompok } \\
\text { A/VCO }\end{array}$} & \multicolumn{2}{|c|}{$\begin{array}{l}\text { Kelompok } \\
\text { B/Zaitun }\end{array}$} & \multicolumn{2}{|c|}{ Jumlah } \\
\hline & & $\mathbf{N}$ & $\%$ & $\mathbf{N}$ & $\%$ & $\mathbf{N}$ & $\%$ \\
\hline Kategori & Beresiko & 2 & 28,6 & 1 & 14,2 & 3 & 21,4 \\
\hline Risiko & $\begin{array}{l}\text { R. } \\
\text { Sedang }\end{array}$ & 1 & 14,2 & 2 & 28,6 & 3 & 21,4 \\
\hline Luka & & & & & & & \\
\hline Tekan & R. Tinggi & 4 & 57,2 & 4 & 57,2 & 8 & 57,2 \\
\hline Jumlah & & 7 & 100 & 7 & 100 & 14 & 100 \\
\hline
\end{tabular}

Tabel 4 menampilkan distribusi frekuensi responden berdasarkan kategori risiko yaitu pada kelompok $\mathrm{A} / \mathrm{VCO}$ dari 14 responden yang termasuk dalam kategori berisiko mengalami luka tekan menurut skala braden sebanyak 2 orang $(28,6 \%)$, kategori risiko sedang sebanyak 1 orang $(14,2 \%)$ dan risiko tinggi sebanyak 4 orang $(57,2 \%)$. Pada 
kelompok B/ Zaitun yang termasuk dalam kategori berisiko sebanyak 1 orang (14,2\%), kategori risiko sedang sebanyak 2 orang $(28,6 \%)$ dan risiko tinggi sebanyak 4 orang $(57,2 \%)$

\section{Riwayat Merokok}

Tabel 5

Distribusi Frekuensi responden berdasarkan Riwayat Merokok di ruang rawat Inap Bedah RSU

Kabupaten Tangerang Tahun 2016
Tabel 6.

Distribusi Frekuensi Responden berdasarkan kejadian Luka Tekan di ruang rawat Inap Bedah RSU Kabupaten Tangerang Tahun 2016 $(n=14)$.

\begin{tabular}{|c|c|c|c|c|c|c|c|}
\hline \multirow[t]{2}{*}{ Variabel } & \multirow[t]{2}{*}{ Kategori } & \multicolumn{2}{|c|}{$\begin{array}{l}\text { Kelompok } \\
\text { A/VCO }\end{array}$} & \multicolumn{2}{|c|}{$\begin{array}{l}\text { Kelompok } \\
\text { B/Zaitun }\end{array}$} & \multicolumn{2}{|c|}{ Jumlah } \\
\hline & & $\mathbf{N}$ & $\%$ & $\mathbf{N}$ & $\%$ & $\mathrm{n}$ & $\%$ \\
\hline Luka & Ada & 2 & 28,5 & 1 & 14,2 & 3 & 21,4 \\
\hline Fekan & Tidak & 5 & 71,5 & 6 & 85,8 & 11 & 78,6 \\
\hline Grade I & Ada & & & & & & \\
\hline \%umlah & & 7 & 100 & 7 & 100 & 14 & 100 \\
\hline
\end{tabular}

\begin{tabular}{lllllll}
\hline Riwayat & Tidak & 5 & 62,5 & 3 & 37,5 & 8 \\
Merokok & Merokok & & & & & \\
& Merokok & 2 & 33,3 & 4 & 66,7 & 6
\end{tabular}

Tabel 5 menyajikan distribusi frekuensi responden berdasarkan riwayat merokok dan riwayat stress. Pada kelompok A/VCO, responden yang tidak merokok sebanyak 5 orang $(62,5 \%)$ dan kelompok zaitun sebanyak 3 orang $(37,5 \%)$.

Responden yang tidak stress lebih banyak baik di kelompok A/VCO yaitu 4 orang $(36,4 \%)$, maupun di kelompok B/Zaitun sebanyak 7 orang (100\%).

\section{Proporsi Kejadian Luka Tekan Grade I Non Blanchable Erytema}

Kejadian luka tekan Grade I Non blanchable Erytema dalam bentuk data akan disajikan dalam tabel 6 .
T2,,9el 6 menampilkan gambaran proporsi kejadian luka tekan grade 1 kelompok A/VCO dan B/Zaitun, dimana kelompok intervensi $\mathrm{A}$ responden yang terjadi luka tekan sebanyak 2 orang $(28,5 \%)$ dan kelompok B sebanyak 1 orang $(14,2 \%)$. Responden yang tidak mengalami luka tekan pada kelompok A sebanak 5 orang $(71,5 \%)$ dan pada kelompok B sebanyak 6 orang $(85,8 \%)$.

\subsubsection{Perbedaan kejadian luka} tekan grade I pada kelompok dengan VCO dan minyak zaitun di ruang rawat Inap Bedah RSU Kabupaten Tangerang Tahun 2016

Pada bagian ini akan dijelaskan hasil analisis bivariate dari variable dependen luka tekan grade I dengan variable independen Utama yaitu 
perawatan pencegahan luka tekan dengan menggunakan VCO dan minyak zaitun.

Tabel 7. Perbedaan kejadian luka tekan grade I pada kelompok dengan VCO dan minyak zaitun di ruang rawat Inap Bedah RSU Kabupaten Tangerang Tahun $2016(\mathrm{n}=14)$. dalam mencegah luka tekan pada pasien yang berisiko mengalami luka tekan

Untuk melihat efektivitas penggunaan VCO dan minyak zaitun dengan massage dalam mencegah luka tekan maka dilakukan uji beda dua mean independen, yang disajikan pada tabel berikut :

$\begin{array}{lllll}\text { Variabel } & \text { Kate- } & \text { Kelomp. } & \text { Kelom. B Juml. } & \text { OR } \underset{P}{\text { OR }} \\ & \text { gori } & \text { A/VCO } & \text { / Zaitun } & (95 \% \text { value } \\ & & & & \text { CI) Tabel 8 Distribusi rata-rata kejadian }\end{array}$
luka tekan dengan intervensi penggunaan VCO dan minyak zaitun

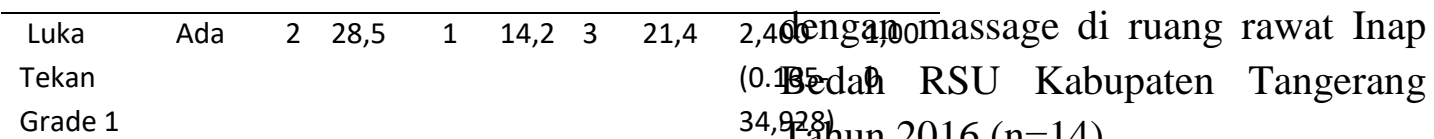
34,928̊hun $2016(n=14)$.

$\begin{array}{lllllll}\text { Tidak } & 5 & 71,5 & 6 & 85,8 & 11 & 78,6\end{array}$

ada

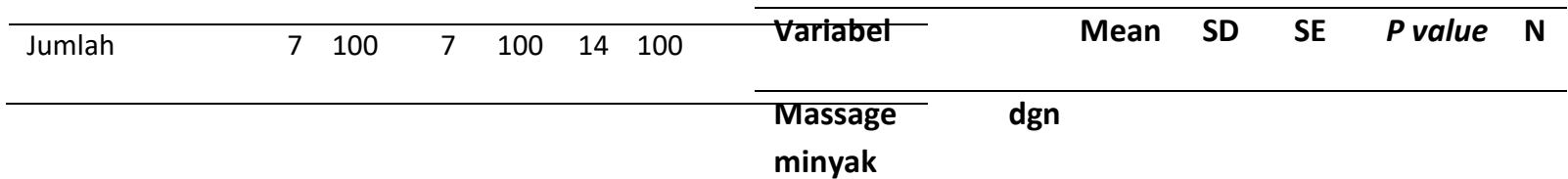

Tabel 7 menunjukkan angka kejadian luka tekan paling besar terjadi pada kelompok intervensi A yaitu 2 orang

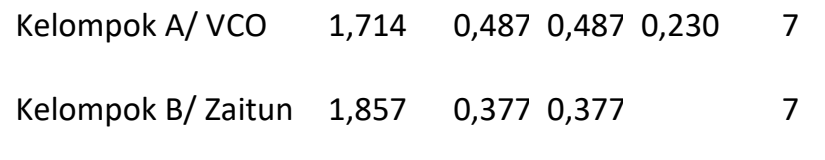
$(28,5 \%)$ sedangkan pada kelompok B/Zaitun hanya $1(14,2 \%)$. Namun pada analisis lebih lanjut tidak terdapat hubungan yang signifikan antara kejadian luka tekan dengan massage menggunakan $\mathrm{VCO}$ dan minyak zaitun, hal ini dibuktikan dengan nilai $p$ value 1,000 .

\subsubsection{Efektifitas penggunaan VCO dan minyak Zaitun dengan massage}

Tabel 8 menunjukkan rerata kecenderungan terjadinya luka tekan pada kelompok intervensi $\mathrm{A} / \mathrm{VCO}$ adalah 1,714 dengan standar deviasi 0,487, sedangkan pada kelompok intervensi $\mathrm{B}$ /Zaitun adalah 1,857 dengan standar deviasi 0,337. Hasil analisis lebih lanjut didapatkan bahwa tidak ada perbedaan selisih rerata 
antara kelompok intervensi A dan kelompok intervensi $\mathrm{B}$ dimana $\mathrm{p}$ value menunjukkan angka 0,230 ( $P$ value $>$ $0,05)$.

\section{PEMBAHASAN}

\section{Karakteristik responden penelitian}

Karakteristik responden pada penelitian ini terdiri dari usia, jenis kelamin, diagnosa medis, kategori risiko dan riwayat merokok.

Hasil penelitian didapatkan rata-rata umur responden pada kelompok A adalah 47,28 dengan standar deviasi 12,04 dan kelompok B adalah 52,57 dengan standar deviasi 10,24. Hasil estimasi interval diyakini $95 \%$ ratarata usia responden kelompok A 36,12 hingga 58,44, sedangkan kelompok B 43,09 hingga 62,04 tahun. Usia mempengaruhi perubahan-perubahan pada kulit. Proses menua mengakibatkn perubahan struktur kulit menjadi lebih tipis dan mudah rusak. Boynton et al (1999) dalan Potter \& Perry (2005) menyatakan 60\%-90\% luka tekan dialami oleh usia 65 tahun ke atas. Usia lanjut (lebih dari 60 tahun) dihubungkan dengan perubahan-perubahan seperti menipisnya kulit, kehilangan jaringan lemak, menurunnya fungsi persepsi sensori, meningkatnya fargilitas pembuluh darah dan lain sebagainya. Beberapa responden ada yang berusia lebih dari 60 tahun, namun rata-rata usia pada kelompok intervensi A maupun B masih berada pada rentang 47,28 - 52,27, sehingga dapat diasumsikan factor usia kemungkinan tidak menjadi faktor risiko terjadinya luka tekan pada penelitian ini.

Pada karakteritik jenis kelamin yaitu pada kelompok A/VCO berjenis kelamin perempuan sebanyak 5 orang $(71,4 \%)$ dan sebaliknya pada kelompok B/Zaitun responden berjenis kelamin laki-laki sebanyak 5 orang $(71,4 \%)$ dari total responden 14 orang. Peluang terpilihnya responden laki-laki dan perempuan sama besar, dikarenakan ruang rawat inap yang digunakan untuk pemilihan responden merupakan ruang rawat laki-laki dan perempuan.

Sebagian besar responden dalam penelitian ini adalah pasien dengan diagnose medis dyspnea dan anemia. Pasien dengan dyspnea umumnya 
mengalami masalah intoleransi aktivitas, dimana kemampuan gerak ekstremitas dapat dilakukan namun untuk melakukan aktivitas seringkali disertai sesak nafas. Diagnosa medis anemia juga merupakan kondisi yang sama, dikarenakan adanya kelemahan, sehingga pasien diharapkan tidak melakukan aktivitas yang berat bahkan sampai bedrest total.

Distribusi frekuensi responden berdasarkan kategori risiko diukur dengan menggunakan skala braden, dimana ditemukan baik pada pada kelompok A/VCO maupun pada kelompok B/ Zaitun rata-rata berada pada risiko tinggi sebanyak 4 orang $(57,2 \%)$. Skala braden mengidentifikasi 6 parameter untuk menentukan risiko luka tekan yaitu persepsi sensori, kelembaban, aktifitas, mobilitas, nutrisi dan gesekan. Skor untuk setiap parameter adalah 1-4, kecuali parameter gesekan skor tertinggi 3, jadi skor akhir antara 6-23. Braden \& Bergstorm (1998) dalam AHCPR (2008) mengklasifikasikan skor total yang diperoleh dalam kategori : tidak berisiko $>19$, berisiko jika skor 15-
18, risiko sedang bila skor 13-14, risiko tinggi bila skor 10-12 dan risiko dangat tinggi bila skor $<9$. Walaupun responden pada penelitian ini berada di ruang rawat inap bedah dan penyakit dalam, namun sesuai dengan pemilihan kriteria inklusi responden, maka kondisi responden banyak tergolong pada risiko tinggi.

Merokok diduga sebagai predictor terbentuknya luka tekan (salztberg et al, 1989 dalam Bryant (2000). Insiden luka tekan lebih tinggi pada perokok dibandingkan dengan yang bukan perokok. Hasil penelitian Handayani (2010) mendapatkan distribusi frekuensi responden lebih banyak yang merokok. Pada penelitian ini juga ditemukan dari 14 responden terdapat 8 responden yang merokok. Afinitas haemoglobin dengan nikotin dan meningkatnya radikal bebas diduga sebagai penyebab risiko terbentuknya luka tekan pada perokok.

\section{Proporsi Kejadian Luka Tekan} Grade I Non Blanchable Erytema

Luka tekan grade I merupakan penanda awal dimulainya perkembangan luka tekan grade 
berikutnya. Luka tekan grade I ini ditandai dengan adanya satu atau lebih tanda kemerahan, pucat, biru, ungu. Nyeri, panas, hangat dan kontur jaringan yang lunak atau keras di suatu lokasi dimana saerah tersebut tertekan dalam waktu lama (.2 jam) tanpa perubahan posisi. Karakteristik lokasi luka tekan terlokalisisr di area tekanan dan membentuk sebuah area kerusakan dengan tepi yang merata sehingga berbeda dengan tanda kerusakan integritas kulit karena sebab yang lain.

Hasil penelitian menunjukkan menunjukkan angka kejadian luka tekan paling besar terjadi pada kelompok intervensi A yaitu 2 orang $(28,5 \%)$ sedangkan pada kelompok B/Zaitun hanya 1 (14,2\%). Namun pada analisis lebih lanjut tidak terdapat hubungan yang signifikan antara kejadian luka tekan dengan massage menggunakan VCO dan minyak zaitun, hal ini dibuktikan dengan nilai $p$ value 1,000. Adanya kejadian luka tekan bila dilihat dari jumlah responden 14 orang baik itu kelompok intervensi VCO ataupu kelompok intervensi zaitun, sama- sama memiliki kejadian yang rendah. Meskipun pada uji hubungan tidak ditemukan signifikansi yang bermakna pada kedua kelompok. Responden dari kedua kelompok intervensi merupakan responden dengan kondisi yang sama, dalam hal ini semua responden dalam kondisi sadar penuh namun responden memang dalam perawatan bed rest total, sehingga tetap saja aktivitas yang dilakukan responden butuh bantuan atau tidak bisa dilakukan secara mandiri. Pada intervensi dengan menggunakan VCO terdapat 2 kejadian luka tekan dan pada intervensi dengan menggunakan zaitun hanya terdapat 1 kejadian luk tekan. Dari perbedaan jumlah kejadian tersebut dapat dilihat bahwa kelompok intervensi zaitun lebih banyak mencegah kejadian luka tekan dibandingkan kelompok VCO.

Hasil penelitian Handayani, 2010 menunjukkan bahwa terdapat perbedaan yang signifikan terhadap kejadian luka tekan grade I antara responden yang diberi perawatan pencegahan dengan VCO dan tanpa VCO. Responden yang diberi perawatan dengan VCO terlindungi 
sebesar 0,733 kali dari kejadian luka tekan grade I dibandingkan dengan responden yang dirawat tanpa menggunakan VCO dan dipercaya 95\% rentang kepercayaan berada pada 0,540-0,995 kali. Hasil uji statistik pada penelitian Yolanda, 2012 menemukan bahwa ada perbedaan yang signifikan antara skor ulkus decubitus setelah pemberian minyak zaitun ada kelompok eksperimen dan kelompok control, sehingga disimpulkan bahwa minyak zaitun efektif dalam mencegah terjadinya ulkus decubitus.

Untuk melihat efektivitas penggunaan VCO dan minyak zaitun dengan massage dalam mencegah luka tekan maka dilakukan uji beda dua mean independen, dimana hasil analisis menunjukkan rerata kecenderungan terjadinya luka tekan pada kelompok intervensi A/VCO adalah 1,714 dengan standar deviasi 0,487, sedangkan pada kelompok intervensi B/Zaitun adalah 1,857 dengan standar deviasi 0,337. Hasil analisis lebih lanjut didapatkan bahwa tidak ada perbedaan selisih rerata antara kelompok intervensi A dan kelompok intervensi $\mathrm{B}$ dimana $\mathrm{p}$ value menunjukkan angka 0,230 ( $P$ value $>$ $0,05)$.

Intervensi perawatan massage ringan dengan menggunakan VCO dapat meningkatkan sirkulasi aliran darah, selain itu juga meningkatkan absorbsi kandungan VCO melalui kulit. Molekul medium chain fatty acids (MCFA) yang kecil mudah diabsorbsi oleh permukaan kulit. Efek pelumas yang dimilki oleh VCO akan menghindarkan kulit yang dimassage dari cedera gesekan akibat massage. Penggunaan secara topical pada kulit diyakini sebagai cara terbaik untuk mendapatkan manfaat VCO. Cara ini akan mengmbalikan elastisitas kulit dnegan cepat dan efektif. (Handayani, 2010).

Penelitian Torra I Bou et all, 2005 dalam Yolanda, 2012 menyatakan bahwa minyak essensial memilki manfaat dalam melindungi kulit terhadap penekanan dan gesekan, memberikan hidrasi yang optimal dan mencegah anoksia sel. Asam lemak yang terkandung dalam minyak meningkatkan kohesif stratum korneum dan mencegah terjadinya 
transcutaneous water loss dan proliferasi sel yang berlebihan. Menurut Khadizah,2008 bahwa minyak zaitun yang dioleskan dapat mempercepat penyembuhan kulit yang luka atau iritasi. Orang-orang Yunani kuno bahkan menggunakan daun zaitun untuk membasuh luka. Daun zaitun mengandung antimikroba dan sangat efektif memerangi sejumlah jamur, virus dan bakteri.

\section{SARAN}

Penatalaksanaan pencegahan luka tekan di rumah sakit merupakan satu indicator kesuksesan keberhasilan keselamatan pasien, sehinga diharapkan rumah sakit dapat membuat SOP terkait perawatan pencegahan luka tekan dengan menggunakan minyak essential baik VCO dan zaitun. Bagi peneliti selanjutnya perlu melakukan penelitian lanjutan dengan menambahkan kelompok control pada masing-masing kelompok intervensi, sehingga dapat dilihat pengaruh yang lebih nyata.

\section{DAFTAR PUSTAKA}

Agrawal Karoon, Chauhan Neha., 2012, Pressure Ulcers : Back to the basics, Indian Journal of Plastic Surgery.45(2):244-254, diakses dari http://www.ncbi.nlm.nih.gov/p mc/articles/PMC3495374/ tanggal 2 Januari 2016

Amin, Sarmidi, 2009 , Cocopreunership Aneka Peluang Bisnis dari Kelapa, Lily Publisher, Yogyakarta.

Ellis,JR \& Bentz,PM, 2007, Modules For Basic Nursing Skills 7ed Vol 1, Philadelphia : William \& Wilkins.

Guy Heidi, 2012. Pressure Ulcer Risk Assessment. Nursing Times. Vol.108 No.4, diakses dari www.nursungtimes.net

Guy Heidi, et.al. 2013. Pressure ulcer prevention : making a difference across a health authority?. British Journal of Nursing.Vol.22 No.12

Handayani Ririn Sri, 2010. Efektivitas Penggunaan Virgin Cococnut Oil (VCO) dengan massage untuk pencegahan Luka Tekan Grade I Pada Pasien yang beresiko mengalami Luka Tekan di RSUD Dr.H.Abdoel Moeloek Provinsi Lampung. 
Tesis.Fakultas Ilmu Keperawatan UI.Depok.

International Olive Council, 2012, Health Benefits of Olives and Olive Oil, diakses dari www.internationaloliveoil.org / tanggal 20 Juni 2016

Jankowski Irene M, 2010, Tips for Protecting Critically Ill Patients From Pressure Ulcers), Critical Care Nurse Vol. 30, No 2, April 2010, diakses dari www.cconline.org tanggal 2 Januari 2016

Joseph Midhun, 2010, To Asses The Effevtiveness of Coconut Oil Massage in Reducing the Risk of Pressure Sore Among NonAmbulatory Patients Admittedin selescted Hospitals At Mysore. Rajiv Gandhi University Of Health Sciences, Banglore Karnataka, diakses dari www.rguhs.ac.in/cdc/onlinecd c/uploads/05_N503_22035 Tanggal 20 Juni 2016

Khadizah, Z, 2008, Khasiat dasyat minyak zaitun. Yogyakarta : Gapura Publisihing.

Lucida et al , 2008, Pengaruh Virgin Coconut Oil (VCO) di dalam basis krim terhadap penetrasi zat aktif, diakses dari http://ffarmasi.unand.ac.id/pub
/Publikasi\%20Sukma.pdf tanggal 22 Juni 2016

Potter PA \& Perry AG, 2005, Fundamental of Nursing, USA; Mosby Inc.

Reddy, Madhuri, Gill, Sudhep S, Roccon, Paula A, 2008, Preventing Pressure Ulcer: A Systemic Review, JAMA 2006; 296 (8):974-984 (doi: 10.1001.Jama.296.8.974) diakses dari http://jama.jamanetwork.com/a rticle. $\operatorname{aspx}$ ? articleid=203224 tanggal 2 Januari 2016

Setyawati Retno, Suyanto, Noor Mohammad Arifin, 2012. Pengaruh Mobilisasi dan Penggunaan VCO (Virgin Coconut Oil) Terhadap Ulkus Dekubitus Pada Gangguan Fungsi Motorik Pasca Stroke. Nurscope Jurnal Keperawatan dan Pemikirian Ilmiah. Jawa Tengah.

Surtiningsih, 2005, Cantik dengan Bahan Alami, Jakarta, Penerbit PT Elex Media Komputindo.

Yolanda Oktari, Utomo Wasisto, Sabrian Febriana. 2012. Efektivitas Minyak Zaitun Terhadap Pressure Ulcers Pada pasien dengan Tirah Baring Lama. Diakses dari repository.unri.ac.id/xmlui/bits 
tream/handle/.../jurnal\%20ook .pdf?...1 1tanggal 2 Januari 2016

Zeller John L, 2006, Pressure Ulcers, The Journal of The American Medical Association Vol296 No.8, diakses dari http://jama.jamanetwork.com/ article.aspx? articleid=203224 tanggal 2 Januari 2016 